\title{
PROSELIT PADA MASA PERJANJIAN LAMA SAMPAI PERJANJIAN BARU
}

\author{
Sariyanto \\ sariyanto@sttefata.ac.id \\ STT EFATA - SALATIGA \\ Adi Chandra \\ adichandra@sttefata.ac.id \\ STT EFATA - SALATIGA
}

\begin{abstract}
In Judaism there are important regulations that require non-Jewish or infidels to convert to Judaism. The terms or conditions that must be met by these non-Jewish believers are known as proselytes. There are at least three conditions that must be fulfilled, namely: the person must attend baptism (mivkah), circumcision for adult males, and make sacrifices. There are two kinds of proselytes, namely: the first is called ger tzedek, which means true proselytes, or truth proselytes. This term is assigned to Gentiles who fully adhere to the doctrine of Judaism, and are considered full members. The second is called a toshav ger or gate proselyte, which means a limited proselyte, or gate proselyte. In this case if someone who lives in the land of Israel and follows some Jewish customs, but is not required to be circumcised or obey the rules prescribed by Judaism. Only they are required to follow the law contained in Noah's law. This proselyte has attracted large numbers of Gentiles from exile, or even during intertestamental times to New Testament times.

In this study, the researchers used the literature method with a descriptive qualitative approach. This research examines in depth the meaning of proselytes, their influence, mission, and development in Judaism. The results showed that the Jewish scholars actively mixed up their religious life so that it became an attraction for non-Jews, as well as they had a strong mission to carry out proselytes. The appeal of the Jewish religion is mainly because they as worshipers of monotheism, have the Torah, a godly way of life for its adherents, and teachers who actively teach the Torah, and the traditions of their religious life.
\end{abstract}

Keywords:intertestamental, proselytism, Judaism, baptism, circumcision, Torah. 


\begin{abstract}
ABSTRAK
Dalam Agama Yahudi terdapat peraturan penting yang mensyaratkan kepada para penganut dari non Yahudi atau orang kafir yang hendak masuk menjadi penganut agama Yahudi. Ketentuan atau persyaratan yang harus dipenuhi para penganut dari kalangan non Yahudi tersebut dikenal dengan istilah proselit. Paling tidak terdapat tiga peryaratan yang harus dilakukan, yaitu: orang tersebut harus mengikuti baptisan (mivkah), sunat bagi laki-laki dewasa, dan memberikan korban persembahan. Proselit terdapat dua macam, yaitu: pertama disebut ger tzedek, yang artinya proselit benar, atau proselit kebenaran. Istilah ini disematkan kepada penganut non Yahudi yang secara penuh mengikuti doktrin Yudaisme, dan dianggap sebagai anggota penuh. Kedua disebut dengan istilah ger toshav atau gate proselyte, artinya proselit terbatas, atau proselit gerbang. Dalam hal ini bila seseorang yang tinggal di tanah Israel dan mengikuti beberapa kebiasaan Yahudi, namun tidak diharuskan untuk disunat atau pun mematuhi aturan yang ditentukan agama Yahudi. Hanya mereka diharuskan mengikuti hukum yang terdapat di dalam hukum Nuh. Proselit ini telah menarik banyak orang non Yahudi sejak dari pembuangan, atau pun pada masa intertestamental sampai pada masa Perjanjian Baru.

Dalam penelitian ini, maka peneliti menggunakan metode pustaka dengan pendekatan kualitatif deskriptif. Dalam penelitian ini mengkaji secara mendalam mengenai makna proselit, pengaruh, misi, dan perkembangannya di dalam Yudaisme. Hasil penelitian menunjukkan bahwa para cendekiawan Yahudi, dengan aktif meramu kehidupan keagamaan mereka dengan baik sehingga menjadi daya tarik bagi orang non Yahudi, demikian pula mereka memiliki misi yang kuat untuk melakukan proselit. Daya tarik dari keagamaan Yahudi terutama adalah karena mereka sebagai penyembah monoteisme, memiliki Taurat, cara hidup yang saleh bagi pemeluknya, dan para pengajar yang secara aktif mengajarkan Taurat, dan tradisi kehidupan keagamaan mereka.
\end{abstract}

Kata kunci: intertestamental, proselit, Yudaisme, baptisan, sunat, hukum Taurat.

\title{
PENDAHULUAN
}

Istilah proselit secara sederhana diartikan sebagai perpindahan keyakinan agama yang dialami oleh orang non Yahudi menjadi penganut agama Yahudi 
atau Yudaisme. Dalam bahasa Yunani menggunakan istilah proselutos, berasal

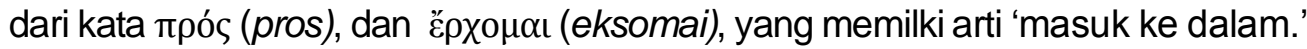
Proselit berkembang dengan suatu pola atau tradisi yang kuat sejak mereka keluar dari pembuangan di Babilonia. Pada zaman Yudas Makabe, seorang putra dari imam Yahudi, Matatias di tahun 167 SM, orang-orang Yahudi melakukan pemberontakan melawan Seleukus Anthiokus IV Epifanes. ${ }^{1}$ Yudas Makabe dikenal dengan gigih mempertahankan keagaman Yahudi dan mempertahankan Yudea, menyucikan Bait Suci di Yerusalem dari kecemaran yang dilakukan oleh pada tanggal 25 bulan Kislev tahun 164 SM, dan dimenegakkan hari raya Hanukah (festival Kenisah, pentahbisan Bait Suci).

Yudaisme tidaklah muncul di dalam Perjanjian Lama, namun muncul pada masa intertestamental, menurut parah ahli bahwa kehidupan orang Yahudi dan mengalami perkembangan yang cukup signifikan setelah 70 tahun keruntuhan Bait Suci pertama, atau ketika munculnya pembangunan dan peresmian Bait Suci kedua pada tahun 515 SM, pada masa Ezra yang ditandai dengan pengorbanan besar-besaran dan disusul dengan hari Paskah, sebagaimana tertulis dalam kitab Ezra pasal 6. ${ }^{2}$ Pembangunan kembali bait suci di kota Yerusalem dalam jangka waktu 70 tahun setelah penghancurannya adalah suatu peristiwa yang sangat menentukan dalam perkembangan Yudaisme, dimana bait suci kembali menjadi pusat ibadah, juga untuk kaum Yahudi yang tetap tinggal di negara lain atau diaspora. Dengan demikian maka Bait Suci menjadi semacam besi berani yang menarik seluruh bangsa Yahudi pada puncak persatuannya. $^{3}$

Kesungguhan Ezra untuk meneliti Taurat dan mengajarkan di antara orang Israel dengan tujuan agar umatNya mengerti rencana Allah bagi kehidupan mereka, dan menjadikan Yahweh sebagai satu-satunya TUHAN yang layak disembah. Pengajaran Ezra kepada orang Yahudi juga ditulis di dalam kitab Nehemia 8:6-9. Pada saat Ezra mengajarkan Taurat, la dibantu oleh orangorang Lewi. ${ }^{4}$ Pengajaran tentang Taurat sejak dari pembuangan ini terus berlangsung dikemudian hari, dan mereka memegang teguh semua ketentuan yang ada di dalamnya dengan tujuan mereka hidup selaras dengan kehendak Allah, hidup dalam ketaatan, dan kekudusan.

\footnotetext{
${ }^{1}$ Michael Collins, and Mathhtew A Price, Millenium, The Story of Christianity, Menelusuri Jejak Kristianitas, Yogyakarta: Kanisius, 2006, hal. 21.

2 Vriezen, Th.C., Agama Israel Kuno, Jakarta: BPK Gunung Mulia, 2006, Hal, 280

3 Ibid, Vriezen, Th.C, hal. 180.

${ }^{4}$ John Piper, Expository Exultation (Sukacita Ekspositoris): Khotbah sebagai Ibadah, Jawa Timur: Literatur Perkantas, 2020, hal. 80.
} 
Dengan demikian maka Yudaisme memiliki akar yang kuat tentang memegang teguh Taurat, sebagai sumber utama ajaran agama, disamping tradisi-tradisi nenek moyang bangsa Yahudi. Bila diperhatikan, maka perkembangan Yudaisme pada masa intertestamental juga tidak lepas dari ajaran yang dibangun pada masa setelah mereka keluar dari pembuangan di Babel. Pada waktu itu Ezra dengan bersungguh-sungguh mengajarkan Taurat kepada umat Israel, sebagaimana ditulis dalam kitab Ezra pasal 7 ayat 10 yang menyatakan bahwa Ezra telah bertekat untuk meniliti Taurat TUHAN, dan melakukan serta mengajar ketetapan, dan peraturan di antara orang-orang Israel. Bila diselidiki maka orang-orang Yahudi mengalami kebangkitan dan kegerakan rohani pada zaman Ezra, Ahli Taurat ternama tersebut. Ezra memberi pengaruh yang sangat kuat untuk mengajarkan dan menerapkan kitab Taurat di tengah-tengah kehidupan orang Yahudi.

Pada masa intertestamental, atau masa antara Perjanjian Lama dan Perjanjian Baru, Yudaisme berkembang dan jumlah pengikutnya terus bertambah, tidak hanya orang Yahudi, tetapi juga terdapat orang-orang dari bangsa lain, non Yahudi. Sedangkan pada masa kemunculan Yohanes Pembaptis, dan kehadiran Yesus, sampai pada masa Rasul-rasul pada waktu pemberitaan Injil, Yudaisme juga berkembang dengan subur dan kerap kali bersinggungan dengan Kekristenan.

Dalam peraturan keagaman ini, orang dari kalangan kafir atau non Yahudi ketika hendak masuk menjadi pemeluk agama Yahudi maka harus mengikuti aturan ataupun ketentuan yang telah ditetapkan di dalamnya. Sekalipun hukum itu dianggap menuntut persyaratan sangat berat namun telah menarik banyak orang dari kalangan kafir untuk menjadi penganut agama Yahudi. Adapun syarat-syarat dari proselit yang harus dipenuhi berdasarkan peraturan agama Yahudi adalah: 1) sunat bagi laki-laki, 2) baptisan, dan 3) mempersembah-kan kurban. ${ }^{5}$ Dalam peraturan atau ketentuan Yudaisme juga berlaku bahwa setiap pemeluknya harus melakukan hukum Taurat sebagaimana yang diperin-tahkan oleh Musa, terutama bagi mereka yang secara penuh menyerahkan diri sebagai Yudaisme. Ketentuan di atas merupakan ketentuan yang sudah baku sebagai syarat utama dalam proselit, di satu sisi proselitisasi memiliki makna yang mendalam, karena setiap penganutnya melabuhkan imannya dari keyakinan atua agama lama masuk ke dalam agama yang baru.

${ }^{5}$ William Goodhugh, The Pictorial Dictionary of the Holy Bible: Or A Cyclopaedia of Illustrations, Graphic, Historical, and Descriptive, of the Sacred Writings, by Reference to the Manners, Customs, Rites, Traditions, Antiquities, and Literature of Eastern Nations (Vol. 2), London: H.G. Bohn, 1845 1845, p.1096. 
Dalam penelitian ini, maka peneliti hendak menggali secara mendalam mengenai proselit pada masa intertastmental sampai pada masa Perjanjian Baru, untuk menemukan penyebab yang menarik timbulnya prinsip-prinsip pertobatan, keyakinan agama, dan cara hidup yang baru di dalam proselit. Demikian juga yang menjadi daya tarik sehingga orang-orang non Yahudi melabuhkan keimanannya ke dalam Yudaisme, dan ketentuan yang harus dipenuhi dalam proselit bagi pemeluk Yudaisme dari kalangan non Yahudi.

\section{METODE}

Untuk menjawab menemukan jawaban dari topik di atas maka dalam penelitian ini digunakan metode pustaka dengan pendekatan kualitatif deskriptif. Lexy J. Moleong menjelaskan penelitian kualitatif adalah penelitian yang bermaksud untuk memahami konsep, perilaku, persepsi, motivasi, tindakan dan lain sebagainya, secara holistik dan dengan cara deskripsi dalam bentuk kata-kata dan bahasa pada suatu konteks yang alamiah dengan memanfaatkan datadata yang tersedia. ${ }^{6}$ Dalam penelitian ini diuraikan dan dijelaskan mengenai makna proselit dalam tinjauan intertesatmental sampai pada masa Perjanjian Baru. Sumber utama dalam penelitan ini adalah pustaka yang mengkaji secara mendalam mengenai proselit, dengan dilengkapi berbagai jurnal dan berbagai sumber yang relevan dalam pembahasan topik proselit.

\section{PEMBAHASAN}

\section{Syarat Proselit}

1. Disunat

Bila menilik penyunatan (circumcision) telah ada sejak zaman Abraham dimana Allah berinisiasi dengan perjanjian tersebut, artinya ini bukanlah peristiwa biasa, namun adalah sebuah peristiwa sakral yang dibangun oleh Allah dengan umat pilihanNya (Kej. 17:10-17). Harun Hadiwijono menyebutkan demikian, arti sunat adalah demikian bahwa, keturunan Abraham dimasukkan ke dalam perjanjian Tuhan Allah, Tuhan Allah berkenan bukan hanya menjadi Allah Abraham melainkan juga menjadi Allah para keturunannya dengan cara yang tampak yaitu dalam bentuk sunat. ${ }^{7}$ Hal yang sangat penting adalah terdapat perbedaan antara umat Allah dan bukan umat Allah, sebagaimana ditekankan dalam Kejadian 17:14, bahwa barangsiapa dari keturunan Abraham tidak disunat orang itu harus dilenyapkan dari antara

\footnotetext{
${ }^{6}$ Lexy J. Moleong, Metode Penelitian Kualitatif-Edisi Revisi (Bandung: PT Remaja Rosdakarya, 2006). Hal. 6

${ }^{7}$ Harun Hadiwijono, Dr, Iman Kristen, Jakarta: BPK Gunung Mulia, 2007, Hal 265.
} 
orang-orang sebangsanya. Para teolog tampaknya sepakat bahwa sakramen selain sebagai tanda, juga sebagai meterai bagi orang percaya. Sakramen sebagai meterai atau cap berfungsi untuk mengokohkan kepercayaan kepada janji-janji Allah. Karena itu menurut Soedarmo meterai berdasarkan Roma 4:11: "Dan tanda sunat itu diterimanya (Abraham) sebagai meterai kebenaran berdasarkan iman yang ditunjukkannya, sebelum ia bersunat. Demikianlah ia dapat menjadi bapa semua orang percaya yang tak bersunat, supaya kebenaran diperhitungkan kepada mereka."

Selanjutnya dalam praktik keagamaan Yahudi pada masa intertestamental sampai masa Perjanjian Baru menjadi isu yang sangat pokok. Peraturan mengenai sunat sendiri dimulai dari penyunatan Ishak ketika berumum 8 hari ( Dan secara turun termurun dilaksanakan oleh bangsa Yahudi, dan upacara sunat ini masuk dalam peraturan dan adat istiadat Yahudi ataupun hukum Taurat (bandingkan dengan Yesus dalam Luk 2:21). Di dalam peristiwan sunat bila memperhatikan di dalam Kejadian 17 maka terdapat tanda (sunat sebagai tanda) penting, yaitu bahwa seseorang secara rohani sebagai umat Allah, dan secara kebangsaan sebagai bagian orang Israel. Namun dalam hal ini secara rohani bahwa Allah memperhitungkan iman Abraham sebagai kebenaran. ${ }^{9}$ Dalam naskah-naskah rabbinik, sunat merupakan suatu keharusan bagi orang non-Yahudi yang ingin menjadi proselit Yahudi dan bergabung sebagai umat Allah (Yudit 14:10; 1 Macc. 1:5, dan Jub. 15:33,34). Seseorang yang ingin menjadi proselit Yahudi maka kepadanya diajukan beberapa pertanyaan. Pertama, mengenai alasan mengapa ia ingin menjadi proselit Yahudi, kemudian apakah ia tahu Israel adalah bangsa yang dianiaya, ditindas, dan dibenci. Jika calon proselit itu menjawab: "Saya tahu, dan saya menerimanya". la juga dilarang untuk makan daging binatang yang haram dan merayakan hari sabat. Jika orang itu menjawab: "Ya, saya menerima", maka ia diterima dan disunat. Jika sunat itu tidak lengkap sebagaimana seharusnya maka ia disunat untuk kedua kalinya segera setelah sunat yang pertama itu sembuh. Kemudian ia dibaptis (Sandmel, 1978: 232, 233)..$^{10}$

8 Dominggus E. Naat, Tinjauan Teologis-Dogmatis Tentang Sakramen Dalam Pelayanan Gerejawi, Pengarah: Jurnal Teologi Kristen, Volume 2, Nomor 1, Februari 2020, Bandung: Sekolah Tinggi AlkitabTiranus. https://journaltiranus.ac.id/index.php/pengarah/article/view/18

9 Van Den End, Th., Tafsiran Akitab: Surat Roma, Jakarta: BPK Gunung Mulia, 2008, Hal. 224

${ }^{10}$ Samuel Benyamin Hakh, Persoalan Status Sebagai Anak-anak Abraham dalam Surat Galatia, Vol 1 No 1 (2016): Gema Teologika: Jurnal Teologi Kontekstual dan Filsafat Keilahian / https://journaltheo.ukdw.ac.id/index.php/gemateologika/article/view/209,mengutip Sandmel, Samuel. 1978. Judaism and Christian Beginings, New York: Oxford University Press. 


\section{Dibabtis}

Persyaratan ataupun ketentuan yang kedua dalam keagamaan orang Yahudi dalah baptisan proselit, yang merupakan keharusan bagi orang kafir bila menjadi pemeluk agama Yahudi. Dalam peristiwa ini maka, orang yang menerima diri untuk menjadi proselit, membenamkan dirinya sendiri ke dalam air. ${ }^{11}$ Para Rabbi telah mendasarkan keharusan baptis proselit pada peristiwa penyiraman yang telah dialami bangsa Yahudi di padang gurun, seperti diuraikan dalam keluaran 24:8. Dalam 1 Korintus 10:12 Paulus juga memberikan sindirannya mengenai hal itu apa yang telah dilakukannya dalam "penyiraman" atau "baptisan di padang gurun" itu secara kiasan, kini dilangsungkan secara nyata oleh Yohanes. ${ }^{12}$ Kalangan proselit menjalani upacara baptis dalam agama Yahudi yang mereka namakan טِרבִ - tevilah, yang wajib dijalani oleh mereka yang non Yahudi ketika mengambil keputusan menjadi penganut agama Yahudi. ${ }^{13}$ Baptisan adalah sakramen yang diperintahkan sendiri oleh Tuhan Yesus. Terminologi yang digunakan dalam Perjanjian Baru bersifat umum. Kata kerja baptisein dan kata benda baptismoi (Markus 7:4) yang berasal dari pencucian Yahudi. ${ }^{14}$

Berbeda dengan baptisan bagi proselit, dimana orang yang mengaku imannya dalam keyakinan agama Yahudi membenamkan dirinya dalam air, maka baptisan Yohanes Pembaptis menjadi tradisi baru, dimana orang yang percaya kepada berita Injil menjadi baptisan yang menunjuk kepada pertobatan. Baptisan itu sendiri bukanlah sesuatu yang dikarang oleh Yohanes Pembaptis, tetapi pada masa itu orang Israel sudah mengenal tentang baptisan proselit, dimana orang-orang dari kalangan kafir atau non Yahudi diterima menjadi umatNya. ${ }^{15}$ Dengan arti bahwa orang-orang Israel sudah memiliki ketentuan, dan mengikuti peraturan keagamaan khusus bagi orang kafir yang masuk ke dalam agama Yahudi. pemandian itu sudah dikenal oleh orang pada zaman Yohanes. ${ }^{16}$ Dan dalam ritual pembaptisan ini maka Yohanes secara aktif melakukan pekerjaan membaptis mereka yang percaya kepada berita tentang kerjaaan Alah, bertobat, dan menyerahkan dirinya untuk dibaptis.

\footnotetext{
${ }^{11}$ Emanuel Martasudjita, Sakramen-Sakramen Gereja: Tinjuan Teol, Liturgis, Pastoral, Yogyakarta, Kanisius, 2003, Hal. 218.

${ }^{12}$ Marinus Hendrik Bolkestein, Keraiaan vang terselubuh, Jakarta:BPK Gunung Mulia, 2004, Hal. 12.

${ }^{13}$ Rita Rahayu, Baptisan Cara Yahudi vs Baptisan Yohaneshttp://www.sarapanpagi.org/baptisancara-yahudi-vs-baptisan-yohanes-vt4381.html

${ }^{14}$ Ibid, Dominggus E. Naat, hal. 9

${ }^{15}$ Ter Linden, Nico, Cerita itu Berlanjut, Jakarta: BPK Gunung Mulia, 2008, hal.3

${ }^{16}$ Verkuyl, J., Aku Percaya, Jakarta: BPK 1966, hal. 236.
} 


\section{Memberikan Korban Persembahan}

Tindakan selanjutnya dalam ritual penganut Yahudi proselit adalah memberikan persembahan kurban. Di dalam masa Perjanjian Lama ritual kurban banyak dituliskan dan dilakukan oleh umat Allah sampai pada zaman Yesus. Di Bait Suci Yerusalem umat Allah memberikan kurban kepada Allah. Syarat bahwa proselit harus mempersembahkan kurban, sudah jelas berasal dari zaman bait suci masih berdiri sudah jelas juga bahwa syarat yang demikian pastilah menjadi keberatan bagi banyak orang dari segi lain tertarik menjadi proselit, mereka memang menjadi yang disebut "orang-orang yang takut akan Allah" (Kisah 10:2; 12; 13: 16). ${ }^{17}$

\section{Dua Jenis Proselit}

Dalam Yudaisme terdapat dua jenis proselit dalam, yaitu, pertama: ger tzedek (memiliki arti proselit benar, proselit kebenaran, proselit religius, proselit taat) dan ger toshav (proselit residen, proselit gerbang, proselit terbatas, proselit separuh). Yang dimaksud dengan seorang "proselit yang benar" adalah seorang kafir yang telah masuk Yudaisme, terikat pada semua doktrin dan ajaran agama Yahudi, dan dianggap sebagai anggota penuh dari orang-orang Yahudi. Dalam hal ini maka para proselit disunat saat dewasa (jika laki-laki), dan dibenamkan (baptis, mivkah) untuk secara resmi melaku-kan pertobatan. Kedua adalah adalah ger toshav atau gate proselyte. Seorang "gate proselyte" adalah orang kafir atau asing yang tinggal di Tanah Israel dan mengikuti beberapa kebiasaan Yahudi. Mereka tidak diharuskan untuk disunat atau untuk mematuhi seluruh Taurat. Mereka terikat hanya untuk mengikuti peraturan dalam hukum Nuh, (jangan menyembah berhala, jangan menghujat nama Tuhan, jangan membunuh, jangan melakukan percabulan (perbuatan seksual tidak bermoral), jangan mencuri, jangan merobek dahan dari hewan yang hidup, dan jangan gagal untuk menegakkan supremasi hukum) untuk diyakinkan akan suatu tempat di dunika yang akan datang.

\section{Latar Belakang Proselit Zaman Perjanjian Lama Sampai Masa Pembuangan}

Dalam kitab Musa diatur bahwa orang yang bukan keturunan dari suku Israel dilarang untuk mengikuti perayaan Paskah, namun membuka pintu bagi mereka yang mengakui iman sebagai proselit dalam perayan ini (Kel. 12-4349). Artinya mereka dapat mengikuti perayaan setelah memenuhi syarat yang ditentukan oleh hukum tersebut, diantaranya adalah sunat. Dimana hukum

\footnotetext{
${ }^{17}$ Harold Henry Rowley Ibadat Israel Kuno, Jakarta: BPK Gunung Mulia, 2009, hal 197.
} 
tersebut diberlakukan untuk orang asli Israel dan orang asing yang ada di tengah-tengah umat Allah.

Pada zaman pembuangan ke Babilonia, orang-orang Yahudi hidup diaspora dan hidup diantara orang-orang kafir dari berbagai bangsa. Pada masa pembuangan, orang-orang Yahudi beribadah dan mempelajari kitab Musa di dalam sinagoge. ${ }^{18}$ Dalam perkembangannya banyak orang-orang non Yahudi yang kemudian tertarik menjadi penganut Yudaisme, khususnya menyangkut cara hidup saleh dan penyembahan monoteisme. Sebagian dari mereka kemudian menyatakan diri bersedia menganut agama Yahudi. Mereka inilah yang disebut dengan proselit. Mereka diharuskan menjalankan semua kewajiban Taurat, terutama sunat, menaati hari Sabat, pantang terhadap makanan tertentu, dan mengakui Yahweh sebagai Allah satu-satunya (bandingkan Kis. 13:43,50; 16:14; 17:4). ${ }^{19}$ Aktifitas di sinagoge ini "terus menarik sejumlah besar orang Yunani untuk datang ke upacara-upacara keagamaan, dan orangorang ini sedikit banyak menyatu dengan masyarakat mereka" (The Jewish War, VII, 45, [iii, 3] $)^{20}$

\section{Proselit Pada masa Intertestamental}

Pada masa setelah pembuangan terdapat keluarga-keluarga yang telah hidup berkecukupan memilih untuk menetap di Babilonia, tidak semua dari bangsa Yahudi memilih untuk kembali ke kampung halaman mereka, mereka berhasil dalam perdagangan, dalam kekaisaran Persia dan dengan Mesir, dari pada ikut kembali ke Palestina dengan persetujuan Koresy. ${ }^{21}$ Dalam masa setelah pembuangan ini, nilai-nilai hidup dan pengaruh orang Yahudi sangat kuat terhadap bangsa-bangsa di mana mereka tersebar (Kisah Rasul 2). ${ }^{22}$ Orangorang kafir ini kemudian tertarik dengan ajaran agama Yahudi. Sebab mereka melihat kesetiaan mereka dalam beribadah kepada Allah, satu Allah saja (monoteisme), meskipun tidak kelihatan dan tidak berbentuk.

Dalam istilah Teologi, masa intertestamental dikenal sebagai masa yang ada antara Perjanjian Lama dan Perjanjian Baru, disebut pula sebagai masa sunyi atau masa gelap, dimana Allah tidak menyampaikan FirmanNya. Secara tradisional,

${ }^{18}$ David Hartono, Istilah sinagoge (Yunani: synagoge), awalnya berarti kumpulan jemaat, kemudian berarti tempat ibadah. Sinagoge ini mulai terbentuk pada masa pembuangan di Babel. Pada masa itu, pusat ibadah beralih dari Bait Suci ke tempat-tempat ibadah lokal yang disebut sinagoge. https://Imsspada.kemdikbud.go.id/pluginfile.php/16188/mod resource/content/1/4.2.\%20Inter testamental\%20Agama\%20\%20Literatur\%20-\%20dh.pdf, diuduh 6 september 2020.

19 Ibid.

${ }^{20}$ Rita Wahvu. dari http://www.sarapanpagi.org/kaum-proselit-vt479.html\#p940

${ }^{21}$ Browning, W. R. F., Kamus Alkitab, Jakarta: Gunung Mulia, 2016.

22 Yakob Tomatala, Teoloai Misi Penaantar Misiologi: Suatu Dogmatika Alkitabiah Tentang Misi, Penginjilan dan Pertumnuhan Gereja, 148-149. 
periode ini dianggap mencakup kira-kira empat ratus tahun, dimana masa setelah Ezra dan Nehemia pulang ke tanah mereka (Yerusalem), dan kembali untuk membangun negeri mereka. Kelanjutan dari zaman ini merupakan zaman yang dikenal dengan nama periode Intertestamental atau masa antar perjanjian. ${ }^{23}$

Pada masa intertestamental ini orang Yahudi cukup lunak untuk menerima orang non Yahudi sebagai penganut Yudaisme, sehingga orang-orang bukan dari Yahudi yang percaya kepada Allah Yahweh, yang kemudian disebut sebagai proselit (Yunani) sebomenoi atau phoboumenoi (bnd. Kis. 13:43). Sehingga menerima tanda sunat, baptisan dan turut mempersembahkan kurban sama dengan orang Yahudi. Arti dari phoboumenoi adalah Orang yang

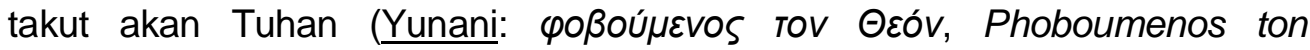

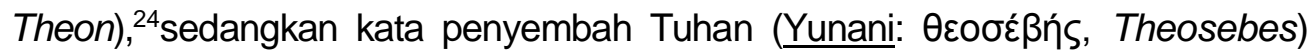
adalah sejumlah simpatisan yang menerapkan ritus dan tradisi keagamaan Yahudi tertentu tanpa sepenuhnya berpindah ke Yudaisme. ${ }^{25}$

Yudaisme pada perkembangannya banyak sekali mendapat pengaruh dari dunia sekitarnya. Artinya bukan hanya taurat dan kitab kitab suci lain yang mempengaruhi perkembangan Yudaisme dalam periode pasca pembuangan, sistem-sistem pemikiran utama agama serta filsafat Persia dan Yunani juga mempengaruhi orang-orang Yahudi, agama zoroastrianisme di kalangan orang-orang Persia mungkin telah memberikan andil bagi penghargaan terhadap malaikat dan penghakiman akhir pada akhir zaman. ${ }^{26}$ Bagi orangorang Farisi menyokong ide-ide ini. Filsafat hellenistis dari pusat-pusat Yunani seperti Alexandria juga mempengaruhi Yudaisme terhadap rasionalisme, dan kelompok Saduki mendapat masukan dari filsafat-filsafat ini.

Keagamaan Yahudi mengalami perkembangan pada masa antara ini namun juga terjadi ketegangan karena munculnya Romawi. Segera setelah itu, tidak mungkin lagi bagi orang-orang Yahudi untuk mencapai sebuah sintesis dengan dunia Yunani titik pada tahun kematian Pilo terjadi pembunuhan sistematik atas komunitas Yahudi di Alexandria dan merebaknya ketakutan akan kebangkitan Yahudi. Ketika Romawi menegakkan imperium mereka di Afrika utara dan

${ }^{23}$ Wen Willyam, Logos, Memra, Dan Yesus: Sebuah Studi Tentang Pengaruh Konsep Logos Yudaisme Helenisme, Memra Yudaisme Palestina Terhadap Konsep Logos Perjanjian Baru (galilee Press, 2018), 32.

${ }^{24}$ David C. \& MacLaren, James S. "Chapter 1, Paragraph 3: God-Fearers". Attitudes to Gentiles in Ancient Judaism and Earlv Christianity. Bloomsbury Publishing. hlm. 15-23. https://id. wikipedia.org/wiki/Orang vang takut akan Tuhan.

${ }^{25}$ Kraabel. A. T. "The Disappearance of the 'God-Fearers"' (PDF). Numen. Brill. 28 (2): 113-126. Diakses tanggal February 5, 2018., https://id.wikipedia.org/ wiki/ Orang yang takut akan Tuhan.

26 Shenk, David, W., Ilah-ilah Global, Jakarta: BPK Gunugn Mulia, 2006, Hal 264 
Timur Tengah pada abad ke-1 sebelum masehi mereka meneng-gelamkan diri dalam kebudayaan Yunani, menggabungkan dewa-dewa nenek moyang mereka dengan dewa-dewa Yunani dan mengadopsi filsafat Yunani dengan sangat antusias. ${ }^{27}$ Pada abad pertama SM Yudaisme begitu kuat, karena di Alexandria kurang lebih 40 persen penduduknya adalah orang Yahudi. pada masa itu orang Romawi juga tertarik dengan Yudaisme. Sehingga banyak orang non Yahudi yang menjadi proselit.

\section{Proselit Pada masa Perjanjian Baru}

Pada masa abad pertama Masehi, dalam Yudaisme sudah terdapat berbagai gerakan atau cabang keagamaan dalam agama Yahudi, diantaranya adalah: orang Farisi dan orang Saduki, Kaum Eseni, Zelot, Herodian, Sanhedrin, Para Ahli Taurat dan para Rabi. Timbulnya aliran/sekte itu disebabkan oleh perbedaan pemahaman yang tentunya dilatarbelakangi oleh perbedaan persepsi terhadap ajaran-ajaran agama beserta cara menginterpretasikannya. ${ }^{28}$ Pada masa ini terjadilah konflik antara orang Yahudi dengan kehadiran Yesus. Yesus yang adalah Mesias hadir sebagaimana dinubuatkan oleh para nabi utusan dari Allah, namun mereka ditolak oleh orang-orang Yahudi. dalam pengajarannya Yesus ditentang oleh para pemimpin agama, ahli-ahli Taurat dan orang -orang Farisi, sebagaimana tergambar dalam catatan Injil. Menurut Markus, masuknya Kerajaan Allah dalam sejarah manusia melalui pelayanan Yesus menimbulkan benturan atau konflik antara Kerajaan Allah dan kerajaan roh-roh jahat. ${ }^{29}$ Pada penganut Yudaiseme, dengan sekte Saduki menolak ajaran Yesus mengenai kebangkitan, dan menyangkal keberadaan para Malaikat (Markus12:18-27). Sekte dari Saduki tidak sepaham dengan pandangan Kaum Farisi (Markus 5:111).

Pada masa ini proselit yang dilakukan oleh penganut Yudaisme masih berlangsung, artinya ada orang-orang yang tertarik masuk menjadi penganut agama Yahudi. dalam Matius 23:15, Tuhan Yesus mneyinggumg para penganut Yudaisme, "Celakalah kamu, hai ahli-ahli Taurat dan orang-orang Farisi, hai kamu orang-orang munafik, sebab kamu mengarungi lautan dan menjelajah daratan, untuk mentobatkan satu orang saja menjadi penganut agamamu (proselutos) dan sesudah ia bertobat, kamu menjadikan dia orang neraka, yang dua kali lebih jahat dari pada kamu sendiri."

${ }^{27}$ Karen Armstrong, Sejarah Tuhan: Kisah 4.000 Tahun Pencarian Tuhan dalam Agama-Agama Manusia, 2011.

${ }^{28}$ Anggun Gunawan, Messianik Yahudi: Juru Selamat Yahudi dalam Telaah Psikoanalisa Erich Fromm, Yogyakarta: GRE Publishing, 2010, Hal. 17

${ }^{29}$ Samuel Benyamin Hakh, Pemberitaan Tentang Yesus, Menurut Injil-Injil Sinoptik (Bandung : Jurnal Info Media, 2008), 29 


\section{Perpsetkif Kristen Mengenai Proselit dan Doktrin Yudaisme}

Membahas mengenai proselit, tidak semata-mata hanya mengenai perpindahan status keagamaan seseorang dari non Yahudi menjadi Yahudi. Karena dalam perpindahan iman tersebut tentulah ada berbagai keyakinan yang melatarbelakanginya. Yudaisme sendiri berkembang dan diakui muncul sejak masa pembuangan di Babel, terutama sejak masa Makabe, dan diterapkannya pada tahun 167 Masehi.

Dalam kaitan ini hal yang mendasar, sebagaimana telah disinggung pada bagian pendahuluan adalah perihal, Taurat, Sunat, Baptisan, Persembahan Kurban. Sejak timbulnya berbagai persaingan dalam sekte Yudaisme, nilai pengajaran di dalamnya pun mengalami pergeseran dan berseberangan. Bagi kaum Farisi mengenai Taurat, mereka tidak mengakui otoritas para nabi, namun mereka menerima nilai-nilai di dalamnya, hal ini berbeda dengan golongan Qumran yang menjunjung tinggi pengajaran para nabi. Golongan Farisi memandang Kitab-kitab Nabi sebagai ulasan yg diilhamkan Allah tentang Taurat, Pentateukh, dan bagi mereka merupakan pernyataan kehendak Allah yang sempurna dan terakhir. Alasan utama mereka menolak Kristus, dan mengapa mereka menuntut tanda dari Kristus, ialah karena Dia mengandalkan otoritas yang ada pada-Nya, bukan yang ada pada Musa. Hal ini menimbulkan perpecahan dalam kalangan orang-orang Farisi dan Ahli Taurat. Dalam Yohanes 9:16 terlihat jelas bagaimana silang pendapat itu bisa diperlihatkan. ${ }^{30}$

Orang Yahudi juga pernah datang kepada Yesus untuk mengetahu pandangannya mengenai Taurat. Yesus mengatakan dalam Matius 5:17, "Janganlah kamu menyangka, bahwa Aku datang untuk meniadakan hukum Taurat atau kitab para nabi. Aku datang bukan untuk meniadakannya, melainkan untuk menggenapinya." Dengan jelas Yesus menegaskan bahwa melalui hukum Taurat dimaksudkan perintah TUHAN yang terdapat di dalam Kitab Musa (Pentateukh), dan kitab para nabi supaya seluruh perjanjian itu digenapi. Di dalam ayat 15:17, ini Tuhan Yesus memberikan penegasan, penjelasan dalam setiap hukum Taurat dalam kitab Musa dan kitab para nabi adalah satu kesatuan. Di dalam hal ini maka Yesus menegaskan bahwa Kristus adalah pelaku penggenapan hukum Taurat, dan ajaran yang baru diberikan oleh Yesus adalah hukum Kasih. Selaras dengan apa yang ditulis oleh Paulus dalam Roma 13:10, "Kasih tidak berbuat jahat terhadap sesama manusia, karena itu kasih adalah kegenapan hukum Taurat."

\footnotetext{
${ }^{30}$ Hendrik Yufengkri Sanda Sekolah Tinggi Teologi Injili Setia Siau, BONAFIDE: Jurnal Teologi dan Pendidikan Kristen www.jurnal.sttissiau.ac.id/Volume 1/Nomor 1/Juni 2020/hal. 144-164.
} 
Pada masa Perjanjian Baru, terdapat orang-orang saleh, dan orang-orang yang takut Akan Allah yang merupakan kaum proselit. Dalam pemberitaan Injil, mereka juga menjadi sasaran dalam pekabaran ini. Injil merupakan pokok dalam pemberitaan Yesus tentang diriNya sendiri, dalam setiap kesempatan la mendobrak adat istiadat budaya Yahudi yang mengkungkung cara hidup keagamaan mereka sehingga menghalangi berita Injil Kerajaan Allah.

Kepada para pendengarnya Yesus mengatakan, "Maka Aku berkata kepadamu: Jika hidup keagamaanmu tidak lebih benar dari pada hidup keagamaan ahliahli Taurat dan orang-orang Farisi, sesungguhnya kamu tidak akan masuk ke dalam Kerajaan Sorga." Kehidupan agama (religi) tidak pernah mengubah pokok permasalahan, karena hanya berurusan dengan hal-hal lahiriah. Itu sebabnya pada kesempatan lain, Yesus mengajar seorang Farisi yang juga pemimpin orang-orang Yahudi, bahwa ia perlu dilahirkan kembali (secara rohani) jika ingin melihat dan menjadi bagian dari Kerajaan Allah. ${ }^{31}$ Dalam hal ini Yesus menegaskan bahwa la adalah orang yang menerima Injil Yesus Kristus, adalah orang-orang yang menerima tatanan baru, yaitu sebagai warga Kerajaan Allah. Bukan lagi seperti kaum Yudaisme atau proselit yang hanya menerima dasardasar dari cara hidup mengikuti peraturan, adat istiadat Yahudi.

Dalam kaitan dengan misi pemberitaan Injil, tentu saat iti ada perspektif yang berbeda; dimana Injil diberitakan kepada orang Yahudi dan bukan orang Yahudi pula. Jika pendapat ini diproyeksikan pada murid-murid Yesus yang pertama, akan berarti bahwa misi yang dijalankan untuk orang-orang yang bukan Yahudi seperti untuk orang-orang Yahudi mengisyaratkan penghapusan penghalang yang sama terhadap berjalannya upacara oleh sebab itu dalam konteks yang tepat sebab bersunat atau tidak bersunat tidak ada artinya tetapi menjadi ciptaan baru (Gal. 6:15). ${ }^{32}$ Sunat menjadi isu penting dalam Yudaisme, karena mereka akan mendapat sebutan baru sebagai orang yang takut akan Tuhan. Dalam Perjanjian Baru, berita Injil menimbulkan kemarahan bagi orang Yahudi, karena Injil tidak menuntut sunat. Dalam Galatia 3, Paulus mengatakan bahwa perkataan yang disampaikan kepada Abraham telah menjadi suatu perjanjian yang dikuatkan oleh sunat, dan itu adalah janji yang diberikan kepada Abraham (Galatia 3).

Dalam kaitan antara perintah dalam hukum Taurat, dan penyunatan dalam Yohanes 7, maka Yesus melancarkan suatu polemik terhadap para penguasa Yahudi dengan menggunakan hukum taurat sebagai titik tolaknya, ketika mereka sedang berusaha membunuhnya dan dengan demikian sebenarnya tidak

${ }^{31} \mathrm{https} / / /$ misi.sabda.org/bagian e apa kesalahan orang orang farisi

${ }^{32}$ Asal usul Agama Kristen, hal. 150. 
mematuhi hukum taurat. Menurut ajaran Yahudi hukum sunat lebih penting daripada hukum hari sabat, dan dengan demikian mereka tidak konsisten. ${ }^{33}$ Yesus orang yang melakukan dan menggenapi hukum Taurat. la disybat pada waktu berusia 8 tahun. Dalam pemberitaan Injil, Paulus membela dengan kuat berita Injil dan menentang pemberitaan tradisi sunat yang dilakukan oleh orang Yahudi, sampai ia dipenjara (Kisah 21:27-36). Di dalam Alkitab sendiri jelas bahwa keselamatan juga mengandung makna universalitas (umum, untuk semua orang) bukan hanya bersifat partikularistik kalau tidak demikian mana mungkin Injil menyebar ke lingkungan yang lebih luas daripada kekristenan Yahudi, yang membatasi keselamatan dalam Kristus hanya pada keyahudian saja. Paulus digambarkan menghantam pembatas ini dalam serangan-nya terhadap praktek sunat yang mau di terapkan oleh orang Kristen Yahudi terhadap orang Kristen Yahudi tetapi oleh banyak orang Kristen sekarang ini cara berpikir orang Kristen Yahudi itu mau diambil alih jadi bukannya mengikuti Paulus tetapi mengikuti lawan lawan Paulus. ${ }^{34}$ Dari sini maksudnya adalah, peniadaan sunat tidaklah kemudian tergantikan dengan baptisan, atau meniadakan sunat juga meniadakan baptisan. Tetapi di sini sunat ditiadakan karena hal tersebut sudah digenapi di dalam diri Yesus Kristus.

Bila sunat memiliki arti sebagai menghilangkan kotoran secara rohani, atau sunat menjadi tanda, maka sudah saatnya bahwa sunat kemudian tidak dilakukan secara fisik, sebagaimana hukum dan tradisi Yahudi. Tetapi sunat yang baru adalah hati yang telah diperbaharui dengan cara menghilangkan semua kejahatan dan kemudian mengenakan hati yang baru, yang penuh dengan Roh Kudus dari Allah. Dalam kita Roma pasal 2:28 -29 disebutkan, "Sebab yang disebut Yahudi bukanlah orang yang lahiriah Yahudi, dan yang disebut sunat, bukanlah sunat yang dilangsungkan secara lahiriah. Tetapi orang Yahudi sejati ialah dia yang tidak nampak keyahudiannya dan sunat ialah sunat di dalam hati, secara rohani, bukan secara hurufiah. Maka pujian baginya datang bukan dari manusia, melainkan dari Allah." ${ }^{35}$ Karena bangsa Israel menolak Yesus bahkan menyalibkan Yesus di atas kayu salib Allah memilih orang yang menerima Yesus sebagai Tuhan dan juruselamat menjadi bangsa pilihan Allah di mata Allah yang disebut bangsa pilihan Allah bukanlah orangorang yang dilahirkan dari garis keturunan Abraham Ishak atau punyaku tetapi

\footnotetext{
${ }^{33}$ Dr. Barclav M. Newman, Dr. Eugene A. Nida Pedoman Penafsiran Alkitab: Injil Yohanes, Jakarta: Lembaga Alkitab Indonesia, 2014, hal. 250

${ }^{34}$ Emmanuel Gerrit Singgih, Berteologi dalam Konteks: Pemikiran-Pemikiran Mengenai Kontekstualisasi teologi di Indonesia, Yogyakarta: Kanisus, 2000, hal. 250.

${ }^{35}$ https://alkitab.sabda.org/passage.php?passage $=$ Rm\%202:2829\&tab=text\#: :text=2\%3A28\%20Sebab\%20yang\%20disebut,1\%20\%2C\%20x\%20bukan\%20 secara\%20hurufiah
} 
orang yang beriman kepada Yesus Kristus tanpa melihat status bangsa mereka. ${ }^{36}$

Baptisan yang menjadi bagian yang sudah dikenal dalam masyarakat Yahudi, pada masa Yohanes Pembaptis telah mmiliki arti baru, yaitu sebagai bentuk pertobatan, dan meninggalkan semau jenis kejahatan. Berita tentang datangNya Mesias, disampaikan oleh Yohanes, ia menjadi pembuka jalan untuk kedatangan Yesus. ${ }^{37}$ Henky menyebutkan: "Misi dalam Perjanjian Baru tidak bisa dilepaskan dari topik tentang kerajaan Allah. Yohanes Pembaptis memberitakan "kerajaan Allah sudah dekat" (Markus 1:15), begitu juga para murid (Luk 10:9, 11). Yesus memberitakan "kerajaan Allah ada di tengah-tengah kamu" (Luk 17:21). Kerajaan ini bukanlah masalah geografis (daerah) maupun politis (bdg. Kis 1:6). Kerajaan Allah menyangkut realitas dan orang-orang. Selain itu, kerajaan Allah tidak hanya terbatas pada bangsa Israel, tetapi seluruh bumi (Kisah Para Rasul 1:6-8)." ${ }^{38}$ Kegiatan pembaptisan bila pada masa Yudaisme adalah sebagai bentuk dari perpindahan iman dan menjadi anggota Yahudi, maka dalam baptisan di dalam perspektif Kristen mengalami pergeseran makna. Baptisan bukan hanya berarti bahwa orang telah berpindah dan masuk menjadi penganut agama Kristen. Bila membaca tulisan dalam Kisah para Rasul, maka ditemukan bahwa usaha untuk pekabaran Injil terus berlangsung dengan giat, sejak terjadinya Pentakosta. Ini adalah momen dan gerakan baru dimana pekabaran Injil menembus orang Yahudi, orang Yunani, Yahudi Proselit. Dalam hal ini maka ciri baptisan bukan hanya baptisan air seperti yang dilakukan oleh Yohanes. ${ }^{39}$ Dalam Markus 1:18 dikatakan: "Aku membaptis kamu dengan air, tetapi la akan membaptis kamu dengan Roh Kudus." Artinya berita Injil sekalipun diterima oleh banyak orang baik di Yerusalem, Yudea, dan Samaria, tidak hanya berhenti kepada baptisan selam. Namun para utusan dari Yerusalem kemudian datang untuk membaptis mereka dengan Kuasa Roh Kudus.

\section{Sebab Sukses Dari Gerakan Proselitisme}

Pada masa Heleno Romawi, Gerakan Proselitisme cukup berkembang dan berhasil sekalipun ada berbagai tantang atau kendala. Kendala tersebut diantaranya adalah sikap dan pandangan monoteisme yang sangat berlebihan

\footnotetext{
${ }^{36}$ Eskatologi, Pdt. J.S. Minandar, Hal 40.

37 Suatu kebangunan rohani yang umum di Yudea dan Galilea menyertai pelayanan Yohanes Pembaptis. Sebagai akibatnya berubahlah suasana rohani di antara rakyat jelata yang membantu menyiapkan jalan untuk penyataan penuh dari Allah di dalam Yesus Kristus, AnakNya yang telah menjelma, https://alkitab.sabda.org/ bible.php?book= Mrk\&chapter=1\#v4, diunduh, tanggal 5 September 2020

${ }^{38}$ Henky Wijaya,Https://Www.Researchgate.Net/Publication/282855064 Misiologi Berdasarkan Perjanjian Lama, 2015, hal 15.

${ }^{39}$ Nelson, Doktrin-doktrin Alkitab,Malang: gandum Mas, hal. 83.
} 
dan radikal. Namun dalam usahan yang gigih, para cendekiawan Yahudi menyajikan agama Yudaisme positif dan semenarik mungkin. ${ }^{40}$ Hal yang lebih penting dalam gerakan ini adalah unsur yang cocok diterima dan ditonjolkan demikian usaha misalnya monoteisme digambarkan sebagai agama luhur yang lebih tinggi daripada kebaktian kepada dewa-dewi kepercayaan akan pencipta dan Tuhan yang maha kuasa dan hakim yang adil menilai tiap-tiap orang sesuai dengan tingkah lakunya. Sedangkan yang kedua adalah daya tarik dari cara hidup (way of life) dalam kehidupan orang-orang Yahudi. banyak orang yang melihat cara hidup orang Yahudi, Agama Yahudi memiliki hukum taurat yang tertulis, dan tradisi lisan yang mengatur tingkah laku orang dengan lebih menyeluruh daripada agama-agama kafir yang dikenal pada waktu. Mereka juga memiliki tempat sembahyang atau synagog untuk beribadah maupun mempelajari Taurat musa. Adapaun yang ketiga adalah mereka juga tetap mempertahankan unsur-unsur tradisional yang kuat secara khusus dalam bidang agama sekalipun mereka berada di bawah Heleno Romawi.

Dalam suatu penelitian yang amat seksama mengenai istilah proses proselitisme dan sunat dalam LXX, M. Simon menarik kesimpulan bahwa gejala proselitisme rupanya sudah muncul bersamaan dengan awal usaha terjemahan LXX sekitar tahun 200 Sebelum Masehi dan menjadi amat penting dalam abad pertama sebelum tarikh Masehi. Dan pada abad pertama muncul kelompok "orang yang takut akan Allah" yang bersamaan dengan kelompok Rasul dan orang Yahudi asli membentuk jemaat synagogue.

\section{KESIMPULAN}

Proselitisme dalam gerakan Yudaisme merupakan bentuk dari perpindahan keyakinan dari orang kafir menjadi pengikut agama Yahudi. Penyelengaraan keagamaan bagi mereka yang masuk dalam agama Yahudi adalah melalui berbagai rangkaian acara atau tradisi keagaman, yaitu: penyunatan, baptisan, dan kurban. Tradisi tersebut berkembang dalam Yudaisme setelah masa pembuangan dari Babel, sampai pada masa Perjanjian Baru. Upaya proselit yang dilakukan oleh orang-orang Yahudi khususnya para pemimin agama tidak lepas dari misi mereka untuk menawarakan system keagamaan yang monoteisme, cara hidup saleh, dan tersedianya buku keagamaan berupa Taurat dan tradisi lisan yang bisa dipelajari di sinagog.

${ }^{40}$ Dr. Wim Van Der Weiden, MSF., Gerakan Missioner dalam kalangan Yahudi pada periode, 220 SM sd $220 \mathrm{M}$. 
Pada abad pertama dimulainya pemberitaan Injil, maka terjadilah pergeseran nilai, dimana pemberitaan Injii oleh Yesus, dan para murid menjadi daya Tarik dan gaya hidup baru yang mendobrak ekslusivisme dari gerekan Yahudi. Gerakan misi pemberitaan Injil telah mengubah dan menggeser tradisi keagamaan Yahudi yang kaku. Kekristenan tidak ditawarkan berdasarkan proselit yang dangkal atau berlangsung dalam sisi fisik belaka. Namun Kekristenan telah membentuk makna baru, yaitu kehidupan yang saleh, pertobatan dan iman kepada Tuhan Yesus Kristus yang telah hadir dan mengorbankan diriNya di kayu salib. Pemberitaan Injil dalam Kekristenan bertujuan untuk menarik semua orang ke dalam Kerajaan Allah melalui Yesus Kristus. Semua aturan yang terdapat di dalam Taurat telah digenapi di dalam Dia; sunat, baptisa, dan persembah kurban telah mendapat makna baru dan lebih rohani.

\section{DAFTAR PUSTAKA}

Anggun Gunawan. 2010. Messianik Yahudi: Juru Selamat Yahudi dalam Telaah Psikoanalisa Erich Fromm. Yogyakarta: GRE Publishing. Hal. 17.

Barclay M. Dr., Newman, Dr. Eugene A. Nida. 2014. Pedoman Penafsiran Alkitab: Injil Yohanes. Jakarta: Lembaga Alkitab Indonesia. hal. 250.

Browning, W. R. F. 2016. Kamus Alkitab, Jakarta: Gunung Mulia.

Dominggus E. Naat. 2020. Tinjauan Teologis-Dogmatis Tentang Sakramen Dalam Pelayanan Gerejawi. Pengarah: Jurnal Teologi Kristen, Volume 2, Nomor 1, Februari 2020, Bandung: Sekolah Tinggi AlkitabTiranus. https://journaltiranus.ac.id/index.php/pengarah/article/view/18.

Emanuel Martasudjita. 2003. Sakramen-Sakramen Gereja: Tinjauan Teol, Liturgis, Pastoral. Yogyakarta, Kanisius. Hal. 218.

Emmanuel Gerrit Singgih. 2000. Berteologi dalam Konteks: PemikiranPemikiran Mengenai Kontekstualisasi teologi di Indonesia. Yogyakarta: Kanisus. hal. 250.

Harold Henry Rowley. 2009. Ibadat Israel Kuno. Jakarta: BPK Gunung Mulia. hal 197.

Harun Hadiwijono, Dr. 2007. Iman Kristen. Jakarta: BPK Gunung Mulia. Hal 265.

Karen Armstrong. 2011. Sejarah Tuhan: Kisah 4.000 Tahun Pencarian Tuhan dalam Agama-Agama Manusia. Bandung: Mizan Pustaka.

Lexy J. Moleong. 2006. Metode Penelitian Kualitatif-Edisi Revisi. Bandung: PT Remaja Rosdakarya. Hal. 6. 
Marinus Hendrik Bolkestein. 2004. Kerajaan yang terselubung. Jakarta: BPK Gunung Mulia. Hal. 12.

Nelson, Doktrin-doktrin Alkitab. 2018. Malang: Gandum Mas, hal. 83.

Shenk, David, W. 2006. Ilah-ilah Global. Jakarta: BPK Gunung Mulia. Hal 264.

Ter Linden, Nico. 2008. Cerita itu Berlanjut. Jakarta: BPK Gunung Mulia. hal.3

Van Den End, Th. 2008. Tafsiran Akitab: Surat Roma. Jakarta: BPK Gunung Mulia. Hal. 224.

Verkuyl, J. 1966. Aku Percaya. Jakarta: BPK, hal. 236.

Vriezen, Th.C. 2016. Agama Israel Kuno. Jakarta: BPK Gunung Mulia. hal. 180.

Wen Willyam. 2018. Logos, Memra, Dan Yesus: Sebuah Studi Tentang Pengaruh Konsep Logos Yudaisme Helenisme, Memra Yudaisme Palestina Terhadap Konsep Logos Perjanjian Baru. Galilee Press.

William Goodhugh. 1845. The Pictorial Dictionary of the Holy Bible: Or A Cyclopaedia of Illustrations, Graphic, Historical, and Descriptive, of the Sacred Writings, by Reference to the Manners, Customs, Rites, Traditions, Antiquities, and Literature of Eastern Nations (Vol. 2), London: H.G. Bohn. p.1096.

Yakob Tomatala. Tahun? Teologi Misi Pengantar Misiologi: Suatu Dogmatika Alkitabiah Tentang Misi, Penginjilan dan Pertumbuhan Gereja. Jurnal Teologi: 148-149.

Samuel Benyamin Hakh, Persoalan Status Sebagai Anak-anak Abraham dalam Surat Galatia, Vol 1 No 1 (2016): Gema Teologika: Jurnal Teologi Kontekstual dan Filsafat Keilahian / https://journal-theo.ukdw.ac.id/ index. php/gemateologika/article/view/209, mengutip Sandmel, Samuel. 1978. Judaism and Christian Beginings, New York: Oxford University Press.

David Hartono, Istilah sinagoge (Yunani: synagoge), awalnya berarti kumpulan jemaat, kemudian berarti tempat ibadah. Sinagoge ini mulai terbentuk pada masa pembuangan di Babel. Pada masa itu, pusat ibadah beralih dari Bait Suci ke tempat-tempat ibadah lokal yang disebut sinagoge. https://Imsspada.kemdikbud.go.id/pluginfile.php/16188/mod resource/c ontent/1/4.2.\%20Intertestamental\%20Agama\%20\%20Literatur\%20\%20dh.pdf, diuduh 6 september 2020.

David C. \& MacLaren, James S. "Chapter 1, Paragraph 3: God-Fearers". Attitudes to Gentiles in Ancient Judaism and Early Christianity. Bloomsbury Publishing. hlm. 15-23. https://id.wikipedia.org/wiki/ Orang yang takut akan Tuhan. 
Kraabel, A. T. "The Disappearance of the 'God-earers' (PDF). Numen. Brill. 28 (2): 113-126. Diakses tanggal February 5, 2018., https://id.wikipedia.org/ wiki/Orang yang takut akan Tuhan.

Rita Rahayu, Baptisan Cara Yahudi vs Baptisan Yohaneshttp: //www.sarapan pagi.org/baptisan-cara-yahudi-vs-baptisan-yohanes-vt4381.html

Samuel Benyamin Hakh. 2008. Pemberitaan Tentang Yesus, Menurut Injil-Injil Sinoptik. Bandung: Jurnal Info Media, 29.

Hendrik Yufengkri Sanda.2020. Sekolah Tinggi Teologi Injili Setia Siau, BONAFIDE: Jurnal Teologi dan Pendidikan Kristen www.jurnal. sttissiau. ac.id/Volume 1/Nomor 1/Juni 2020/hal. 144-164.

https://misi.sabda.org/bagian e apa kesalahan orang orang farisi

https://alkitab.sabda.org/passage.php?passage=Rm\%202:2829\&tab=text\#: : :text=2\%3A28\%20Sebab\%20yang\%20disebut, $1 \% 20 \% 2$ C\%20x\%20bukan\%20secara\%20hurufiah

https://alkitab.sabda.org/bible.php?book=Mrk\&chapter=1\#v4, diunduh, tanggal 5 September 2020

Henky Wijaya. 2015. Https:/Www.Researchgate.Net/Publication/282855064 Misiologi Berdasarkan Perjanjian Lama. hal 15.

Dr. Wim Van Der Weiden, MSF. Gerakan Missioner dalam kalangan Yahudi pada periode, 220 SM sd 220 M. https://e-journal.usd.ac.id/ index.php/ job/article/view/1285 
SIAP, Vol. 10 No.1, Juni 2021: 89-108 